Tetyana Deyneka,

D.Sc., Associate Professor, Higher Educational Establishment of Ukoopspilka «Poltava University of Economics and Trade», Ukraine

Olga Shkurupii,

D.Sc., Professor, Higher Educational Establishment of Ukoopspilka «Poltava University of Economics and Trade», Ukraine

Kseniia Verhal

Ph.D., Associate Professor, Higher Educational Establishment of Ukoopspilka «Poltava University of Economics and Trade», Ukraine

Nataliia Bazavluk

Ph.D., Associate Professor, Higher Educational Establishment of Ukoopspilka «Poltava University of Economics and Trade», Ukraine

\title{
Global status of countries: determination and interpretation
}

Abstract. The study of the place and role of countries in the system of modern international relations is due to the need to identify asymmetries and contradictions that are inherent in a globalizing society. The paper is aimed at determining the global status of countries and to interpreting the present state of their positioning. Summarizing the scientific principles that form the idea of the state of the global society and options for its possible transformation confirms the relevance of the analysis on this issue. The paper presents an approach to the parametric estimation of the global status of countries, the necessity of which is due to the unresolved problem in the thematic field of these scientific studies. The methodological basis for determining the global status of countries is the synthesis of the effects of the internal factors of the national systems development by the spheres (economic, technological, social, spiritual and cultural, political, as well as the functioning of state institutions, and natural resource management), the synergistic effect of the interdependence of all components of such social and natural complexes (the effects of the aggregated endogenous factor) and the effect of globalization (the exogenous factor). By an aggregate assessment of the situation, the status of countries reflects the current picture of the world and the configuration of forces in the system of modern international relations and is also considered as a functional transformation of the globalized world. The method of scientific analysis is agglomerative clustering, conducted with a software algorithm and implemented in Python. An empirical analysis is based on data from international organizations for 2018. The analysis involves data from 142 countries. The research empirically confirms and theoretically proves the fact of the modern world asymmetry, which is a serious challenge to a globalized society. At the same time, the emergence of asymmetry is a warning; a signal of the existence of a threat of systemic contradictions on a global scale. Therefore, asymmetries contain not only the potential of destruction but also the potential for a qualitatively better restructuring of the world. Taking into account this fact and continuous monitoring of changes based on the assessment of the global status of countries allow to identify the options for the future development of civilization and to prevent such negative phenomena as global problems, risks, crises and others, including the global catastrophe.

Keywords: globalization, globalized society, the global status of countries, country positioning, contradiction, asymmetry.

Introduction. Nowadays, when, as a result of active centripetal processes, the world has approached the state of being globalized, there started to simultaneously show the opposite (centrifugal) processes, related to the formation of the countries positions, which would determine their role in the new format of international relations. In the course of modern integration processes, growing contradictions within the world system become apparent, which is caused by the divergence of economic states of the countries, the distinction between their international, in particular political, statuses, as well as the factors determining the specifics of the development of each separate country: the effectiveness of institutions, culture, spirituality, ecology, etc.

Cite as: Deyneka, T., Shkurupii, O., Verhal, K. \& Bazavluk, N. (2019). Global Status of Countries: Determination and Interpretation. Marketing and Management of Innovations, 4, 216-228. http://doi.org/10.21272/mmi.2019.4-17 
Firstly, the place of each of the countries in the modern world is significantly dependent on the internal factors of the development. The most important among them are the factors that determine the effectiveness of functioning of the economic mechanism (the basis of the development of national macroeconomic systems) and the ones that contribute to the excellence of policies conducted by the governments of the states in various spheres of society, as well as in the international arena. Ensuring a worthy place in the system of international relations is a crucial task for each country, which also essentially depends on the effectiveness of the actions of society in preventing the aggravation of contradictions (and ideally in their solution). Contradictions arise in all spheres of vital activity of society, which is objective. They constantly accompany the internal development of socio-economic systems. Therefore, only a sequence of public actions aimed at preventing them can preserve/improve the global status of states and their peoples.

Secondly, the place of the countries which they occupy in a modern globalized world is determined by external factors. They can also contribute to the development of a particular country, by strengthening its role in the system of international relations or hamper the progress, causing external threats to the economy, state sovereignty, and the system of national spiritual values.

Literature Review. The life of the mankind (present and future) determines the conditions of institutionalization of the world order (including the economic one), which in turn essentially depends on the configuration of the forces in society - the place and role of certain countries in the system of international relations. Given the importance of determining the way a society should follow, the above problem is actively investigated in a broad interdisciplinary field. It is formed by such sciences as economics, political science, sociology, and others. The need for a comprehensive analysis of the phenomena and processes taking place in a globalized society is due to the fact that the opportunity to properly evaluate them, as well as to determine the options for the future development of civilization, arises only under the condition of a comprehensive perception of reality.

J. Naisbitt (2003) in particular, defining modern megatrends, pointed out that the essence of society's wealth is now changing. High technologies, technological advancements are closely intertwined with the social and spiritual life of society, as well as with the environment. The economy is changing significantly - a new global model of the division of labour is being approved, and the world economy is being structurally rearranged. The institutional system transforming is mediating the life of modern society. A new institutional paradigm of entrepreneurship, consumption, and the social sphere (education, healthcare, etc.) is gaining ground; there occur trendy political changes.

In terms of the investigated problem, it is necessary to mention the work of such scholars as D. Acemoglu and J. Robinson (2017), who are considering in detail the peculiarities of the forms of institutionalization of modern international relations. They attribute the decline of nations to the dominance of the extractive institutions in poor countries created to extract income and benefits from one social group for the sake of another one and consider the inclusive institutions (economic and political) to be the cause of the wealth of nations. The inclusive economic institutions contribute to the development of technology and education, which in turn stimulates the production of the use of all types of resources (labour, land, capital); the inclusive political institutions are crucial for the development and creation of the country's wealth. By distributing power, they tend to eradicate the economic institutions which expropriate the resources of the many, erect barriers to the market entry, and suppress markets for the benefit of just a few.

Due to the fact of changing the place and the role in the system of international relations of developing countries, the study of J. Ikenberry (2016) is becoming the most significant nowadays. The researcher emphasizes the special mission that these countries acquire in the processes of institutionalization of international economic relations. He points out that the international mutual aid community is now being formed, a kind of club for new leader economies that provides its members with economic and political 
development tools; creates favourable conditions for trade, introduces mechanisms of conflict resolution, defines the framework of collective action, provides its allies with security guarantees, resources during the crisis and so forth.

The analysis of the world economy in retrospect and the long view (by 2030) was performed by E. Madison (2012), global and civilization dimension of modern economic development - by V. Tarasevich (2017), estimation of the global economic development (its potential, driving forces, trends, asymmetry) by D. Lukianenko, A. Poruchnik, V. Kolesov (2013), investigation of the essence and tendencies of reconstructive development in the aspect of economic efficiency and social justice - by V. Heiets, $A$. Hrytsenko (2016).

A special scientific position on the present and future of the life of mankind belongs to U. Beck (2012), who defines its state as a «global risk society» and indicates that the current world is characterized by the accumulation of risks (environmental, financial, military, information and other ones) and potentially - a disaster.

The principles of resolving the contradictions of the development between the desire of mankind for a constant increase in well-being and the "finite planet" insufficiency were developed by A. Benoist (2012). The researcher argues that to provide conditions for the further progress of civilization, it is necessary to proceed from the need for self-sustaining development (from its direct dependence on the ability of society to preserve the environment), and not from the need for sustainable growth.

K. Polanyi (2002) pointed out the contradiction of social and economic aspects in the life of the global society, which caused the dynamics of the era, and manifested in the sphere of distribution. The sociological aspect of the changes taking place in the XXI century and their systemic nature were investigated by I. Wallerstein (2004). He described the existence of many states intertwined with a system of interstate relations, thus defining the content of the world economy and its belonging to the world-system - a certain organically formed territorial space, covering many political and cultural units, all activities of which are subject to system rules.

However, despite the existence of many theories about the prospects of the future world-formation (both optimistic and fatalistic), the system of scientific views on the options for the development of the world as integrity, which is formed by the countries, continues to be formed. And in this regard, there is a request for a methodology that considers the complexity, diversity, and the contradictory nature of the life of a globalized society. It is also necessary to find a toolkit that allows you to define and interpret the global status of countries.

The above determines the task of the study. The purpose of the paper is to determine the global status of countries and to interpret the existing state of their positioning based on hierarchical cluster analysis.

Methodology and research methods. A review of the scientific literature has shown that the methodology for the study of the global status of countries should be based on the principles of interdisciplinary analysis. This makes it possible to fully assess the contribution of all spheres of activity of society to the development of each country. Therefore, studies of the global status of countries define the generalized methodological principles according to which each country is considered as a social and natural system. The components of this system are the spheres of society's life: economic, technological, social, spiritual and cultural, political, as well as the functioning of state institutions, and natural resource management. The country's holding a certain place in the system of international relations is a consequence of the effectiveness of functioning of each of these areas. Accordingly, the positions of countries in the field of economy are estimated by the Global Competitiveness Index; in the field of technology development - by the Global Innovation Index; in the social, spiritual and cultural fields - by the Human Development Index; in the field of politics and institutionalization of relations - by the Fragile States Index; in the field of human interaction with nature - by the Environmental Performance Index. The synergistic effect of interacting and interrelated spheres of human activity is an aggregated factor of 
endogenous origin. Because of this, the Legatum Prosperity Index (LPI) has been chosen as its indicator. Besides, the global status of the countries is influenced by the synergistic effect of the interdependence of all components of the social and natural system (the effect of the aggregated endogenous factor) and the impact of globalization, due to the specificity of its modern manifestation (the effect of the exogenous factor, which is estimated by the Index of Globalization KOF).

Methodological support of the analysis of the global status of countries is based on the use of clustering. The Ward's agglomerative hierarchical method, which implies the use of the Euclidean metric, was applied. Hierarchical cluster analysis (HCA) was used to interpret the global status of countries.

A hierarchical cluster analysis of $n$ objects is determined by a step algorithm, which combines two objects with the smallest difference at each step. The scheme of agglomeration clustering assumes the following: the beginning is the definition of clusters $\mathrm{K}$ at the level $\mathrm{j}=1$; at each higher level in the hierarchy, two clusters are combined based on the degree of similarity between cluster pairs. The procedure is repeated until one cluster is left at the upper level. The result of cluster analysis is a binary tree, or dendrogram, with $n-1$ node. The branches of this tree are «cut» at the level where there is a lot of «space», that is, where the jump in the levels of the two consecutive nodes is large (Greenacre and Blasius, 2006). The hierarchical clustering of countries, undertaken to identify their global status, was carried out using a software algorithm and implemented in Python.

The input for the cluster analysis system was the official publications of international organizations, data from research expert rating agencies, business schools, institutes, universities, and think tanks. The set of international indices determined based on methodological approaches of these organizations, form logically ordered instruments for studying the global status of countries.

Results. The authority of a state in the world arena is determined by its place and role in the system of international relations. This so-called «baggage» has its own «weight» or "price» for each country. The fact is that its acquisition/loss lead to a change in the position of the state in the modern world. The global status of countries is formed by society performance in all areas of activities. Under the current conditions of society development, the status of countries in the system of international relations is determined by several reasons caused by the processes taking place in the key areas of human life: economic, technological, social, spiritual and cultural, political, as well as functioning of state institutions, and natural resource management.

Given the role of the economy in the life of mankind, which is the material basis of its development, the clarification of the discrepancy in the global status of countries must precisely begin with the economic development. The modern global economy is multifaceted. It features industrial, post-industrial, innovative, information, digital, virtual, and some other segments. Their presence is due to the divergence of technological development of the countries and regions of the world. Thus, in our time the status of the above countries and regions is essentially dependent on the presence/absence of technical and technological advantages in some of them, compared with others.

However, the impact of technologically and economically developed countries is not limited to causing inequalities in the development of economic systems and disparities in economic relations between countries. It also extends to the sphere of political, ideological and other social relations, in the aggregate causing transformations in the form of a change in the balance of power between countries. Different technological levels of development and economic discrepancies between countries thus lead to stratification into groups of states based on their political influence, as well as to social and civil stratification. In general, that leads to the inequality of the competitive capabilities of national systems, which are formed based on the development of all spheres, including the sphere of human-nature interaction.

Consequently, the global status of the country is its relative position in the system of international relations, which is determined by several key factors: 1) economic development, 2) advances in the field of science, technology and innovation, 3) the development of social sectors (healthcare, education, social 
protection), 4) the result of the distribution and implementation of power within the state (domestic policy) and between states (foreign policy), 5) the efficacy of institutions, 6 ) the effectiveness of natural resource management. Thus, the global status of the country as an aggregate set of properties of the entity of international relations determines the place of the state in a globalized world for a certain historical period. Acquiring another global status, as compared to what was before, reflects the status dynamics - a change in the role played by the country in the system of international relations, that is, the transformation of its behaviour in the world arena.

The most common approach to determining the positions of countries in the world is to divide them into developed countries (advanced economies), emerging and developing countries (developing economies). Such an approach to the division of countries should be considered as the key one, which is explained by the importance of the development of socio-economic relations (property relations) and techno-economic ones for the society at any historical stage of its existence. Hence, it is natural that advanced economies are both technology leaders and the most influential political players at the same time. The vast majority of economies are socially oriented, which provides a high standard of living for the population and influences the transformation of cultural and spiritual values in society.

However, even under the condition of the assessment of the role of countries in the economy, there are differences in the identification of their positioning, when different indicators are applied to this analysis. The United States, the G-7 countries, China, Singapore, India will change leadership positions if compared by different criteria, such as output, investment flows, natural resource availability, or by such factor of production as labour. Consequently, if the purpose of scientific analytics is to determine the status of countries in the world economy, it is necessary to apply the methodology involving such methodological tools, which allow generalizing the disparate blocks of analysis.

A generalizing approach to the analysis of the status of countries is all the more necessary in the case when the task is to identify asymmetry, which is the immanent sign of a single (economic, political, social, spiritual) geospace of the multipolar world, taking into account the fact, that the qualitative transformation of life of a planetary society is impossible without the formation of a harmonized social and natural complex. Such a complex is formed by an integrated social system (economic, political, social, spiritual), and the system (sphere) of human interaction with the natural system. The development of a set of spheres in their synergistic interaction forms the quality of the world social system as a whole. Accordingly, countries should also be considered as social and natural systems, structurally formed by spheres. The achieved development effect (accumulated systemic quality) thus effectively determines their status in a globalized world.

Clustering countries by the level of their economic development for a long time provided for distinguishing, in addition to the countries with a prevailing market economy (developed countries) and countries the economies of which are in the process of forming market relations (developing countries), the countries with transition economies. These are the post-socialist countries belonging to the bloc of the socialist community countries, including the former USSR republics. Now the transition to a market economy in the mentioned above countries is completed, and the results of the systemic transformation of states are different. Both external factors of social and economic development of countries and internal ones played their roles. Reorganization of the economic system based on a market mechanism produced a different effect, the transformation of institutions and political principles in the external and internal spheres of state influence became different in-depth, various changes took place in the social and spiritual life of the countries, and the relations of natural resource management were formed differently. Some countries have made more progress (in particular those which chose the course of European development and successfully implemented it), the others achieved less progress.

An analysis of the changes in the place and role of the countries of the former Soviet Union, as well as in the countries of Central and Eastern Europe in terms of how successful they were in respecting 
European values, is of particular interest. In spite of several contradictions that are inherent in the European Union nowadays, the interaction effect achieved within this intergovernmental integration association can provide a favourable impact on the economy, politics, development of the social sphere, and the standard of living of society of an individual state as a whole. At the current (most recent) stage of development of this unique form of interstate economic and political integration, it is evidenced by the EU Budget Draft for 2021-2027 (2018). The content of this document reflects the prospects for building interstate relations, constituted in the principles and criteria of cooperation between the EU member states, which are also a requirement for other countries seeking to become the EU member states. According to the title «A Modern Budget for a Union that Protects, Empowers and Defends», the EU Budget Draft for the years 2021-2027 declares the intention that this intergovernmental integration association will continue to prevent global challenges, promote the expansion of opportunities for the development of member states and protect their interests.

In this aspect, Ukrainian analysts (Poliovyk, 2018), point out that the document identifies the priorities and prospects for international programs of the EU that are of interest to Ukraine or programs that are implemented with the participation of the EU member states and partner states will affect its national and geopolitical interests. That is, the priority programs and directions of the European Union activities, outlined in the document, will determine the vector of geopolitical orientation for Ukraine's foreign policy and will set out the emphasis both in its national and international programs, which will depend on European partners. However, for its part, to become a worthy entity of the international relations, the country must ensure, first, an effective system of political relations on the principles of association between Ukraine and the EU and economic links on the principles of economic integration.

To identify the place of countries in modern international relations (their global status) and their role (behaviour which is due to their positioning), a generalized methodological approach to studying this scientific problem is offered. It proceeds from the principle of aggregation of information, which characterizes different but interrelated spheres of human life. They include the following spheres: economic, technological, social, spiritual and cultural, political, as well as the sphere of functioning of state institutions, and natural resource management. Taken together, these spheres form a social and natural complex or otherwise a social and natural system of the countries.

The parametric estimation of the processes taking place in the sphere of economy is carried out through measuring the global competitiveness (Global Competitiveness Index, $\mathrm{GCl}$ ), taking into account the fact that the real value of the economic potential created in the country shows only under the conditions of competitive relations. The country's technological potential can be evaluated through innovations (their radical nature and extension) since innovation itself is the embodiment of the potential. The indicator is the Global Innovation Index (GII). The processes taking place in the social, spiritual and cultural spheres of the countries are best identified by the Human Development Index (HDI); in the fields of policy and operation of public institutions - Fragile States Index (FSI); in the field of natural resource management the Environmental Performance Index (EPI).

Also, the synergistic effect of all components of the socio-natural system of each country is taken into account, because the development of these systems cannot be linear. All social and natural systems without exception have intrinsic non-equilibrium dynamics, openness and self-organization. Therefore, the synergistic effect can ultimately prove to be positive, negative or neutral. Consequently, there is a need to assess the overall effect of dependence and conditionality between the spheres of the socio-natural complex of countries. In our opinion, the criterion for such an assessment is the success achieved by the country in creating national wealth. The indicated synergistic effect of interacting and interrelated spheres of human activity is an aggregated factor of endogenous origin. Because of this, the Legatum Prosperity Index (LPI) has been chosen as its indicator, since this indicator takes into account various aspects of human life - economy, entrepreneurship, governance, education, healthcare, security, personal freedom, 
social capital, and the environment.

Nowadays, any country is included in the system of international relations. Therefore, along with internal factors (the general factor of synergistic action and partial ones - in spheres), which determine the place and role of states in a globalized world the influence of the external environment should also be considered, which, under the present conditions, is special. Specifying the features of this peculiarity, firstly it should be pointed out that today two diametrically opposite forces are manifesting themselves - natural globalization (or, in other words, horizontal globalization) and controlled globalization (or, in other words, artificial or vertical globalization). Secondly, the consideration is that the external environment in which the development of national systems is taking place, and which is essentially globalized, is currently in the active phase of transformation as a result of the expansion of an all-embracing process of informatization.

In our time, globalization has acquired special forms such as information globalization and / or «new globalization». Information globalization is a product of a large-scale digitalization of society as a result of the spread of the latest technologies - mobile, cloud, business intelligence based on digital technologies, social media. «New globalization» has absorbed all signs of information globalization, but it is interpreted with a somewhat different emphasis. According to Jeffrey D. Sachs, «new globalization» is the globalization of the digital era. Its most important technologies are information, communication and transport. The process of «new globalization» is mediated by the activities of TNCs, and the key role in its occurrence is played by geopolitical changes along with the technologies. The novelty is that the combination of innovative technologies and changes in geopolitics creates a system of economic interactions much more intense than before (2011). Under these conditions, in our time, the most obvious is the planetary integrity that is formed based on the universalization of the economic sphere, and, therefore, of all other spheres of the life of society.

The two above-mentioned key factors that determine the specifics of the environment are interconnected. That makes the external environment, where the national systems operate, contradictory. This contradiction is generated by the fact that globalization is both a cause and a consequence of the problems that arise under the conditions of technogenic civilization development, which is generated by society (by human activity in the broad sense). Confirming this fact, scientists (Demidenko et al., 2011) note the objectivity of globalization as an evolutionary process of technogenic genesis of society and nature. The main determinant of globalization processes is the technogenic society, which directs socionatural development in the interests of technologically developed countries and TNCs.

In fact, on the one hand, the modern world economy is largely a product of artificial globalization, which is formed by the most influential entities of international relations. In the twenty-first century, their power is substantially superior to the power of objective market processes of the world economic development. However, on the other hand, the current world development is impossible without the institutionalization of relations that take place at the supranational level. The institutions of global governance/regulation are the foundation of the world economic order. Their productivity is estimated by the effects that arise in the global economy as a result of the implementation of common strategies, norms and rules. A specific global order as a whole, as well as in certain spheres of the globalized society, is shaped by functioning institutions - working rules and rules-in-use (terminology by Ostrom, 2007). Consequently, due to the sum of these trends further development of the world society is likely to be within the framework of a mixed model of global governance/regulation («national states + intergovernmental organizations + TNCs + civil society»).

Today, the form of a social organization is more in line with the world order, which is institutionalized as a polymer sum (a model of a multipolar, polycentric world). Under these conditions, the global status of national systems (their relative position - the place in the system of international relations) and the status dynamics (change of role-behaviour) essentially depend on how interrelated and separated countries and peoples reach agreement on needs and interests. That is, the existence of competition between countries 
for the variants of institutionalization of the world order relations creates preconditions for the emergence of various modifications of the multipolar world, which are possible due to the changes in the global status of countries and their behavioural reaction (ability to negotiate).

Multiplicity without unity - the state to which the modern type of social organization of the world society approached - involves the formation of leading world economic centres (if to talk about the economy) and centres of power or poles of the world order (if to generalize all aspects of the functioning of a globalized society). In each particular case, these changes will trigger appropriate changes in the environment, which will also be accompanied by various options for the correlation of the impact of natural and controlled globalization.

To estimate the aggregated influence of external factors on the status of national systems operating in the global environment is possible due to the integral index of globalization of countries (Index of Globalization KOF). It reflects the degree of the country's inclusion in the processes of globalization and is determined by the three integration «pools»: economic, political and social ones. Consequently, the method of its calculation substantially considers the complexity of modern national social systems at the national and supranational (regional and global) levels, as well as the specifics of the modern manifestation of globalization.

The aggregation of a general indicator identifying the global status of countries is based on a set of attributes that determine the position of each country in international ratings. The information on the country's place in the ratings allows us to approach the assessment of changes taking place in national systems through the use of partial indicators that reflect the development of the economy, politics, state institutions, science, innovation, education, natural resource management and other areas of human activities. To compare the economic systems of different countries and estimate the asymmetry of the global economic development, the World Economic Forum (WEF) rating was selected, the methodology of which is used to calculate $\mathrm{GCl}$. The technological development of different countries is determined by the ratings of the INSEAD (India's Confederation Industry), the World Intellectual Property Organization, the Cornell University and the International business school «INSEAD». According to their methodological approaches, GII is calculated before rating. An overview of the differences in the development of social, spiritual and cultural spheres in different countries is provided by an analysis of the United Nations rating according to which HDI is calculated. The methodology developed by the Fund for Peace allows us to assess the effectiveness of the processes occurring in the areas of politics and the functioning of state institutions in different countries. According to it, the rating of fragile states is determined and the corresponding index (FSI) is calculated. The ranking of the Yale Center for Environmental Law and Policy allows us to assess the effectiveness of the processes in the field of natural resource management based on EPI.

The use of international ratings also allows us to assess the impact of endogenous factors of countries development in the aggregate and also (in the aggregate) the impact of exogenous ones. The result of the interaction of all spheres of the socio-natural complex (internal synergistic effect), which is considered as a factor in the concerted action of the subsystems of the national system, clearly reflects The Legatum Prosperity Index. It is calculated based on data from reputable international organizations (the UN, the World Bank, the Organization for Economic Co-operation and Development, the WTO), institutes (Gallup), companies (Economist Intelligence Unit, IDC, Pyramid Research), etc. The impact of the environment is estimated using the Index of Globalization KOF proposed by the KOF Swiss Economic Institute (another name is the KOF Konjunkturforschungsstelder ETH Zurich).

To study the global status of countries, the data for 2018 was processed. The following number of countries was subject to analysis by the following indices: $\mathrm{GCl}-140, \mathrm{GI}-126, \mathrm{HDI}-189, \mathrm{FSI}-178$, $\mathrm{EPI}-180, \mathrm{LPI}-149, \mathrm{KOF}-203$. However, given the need to fully reflect the factors that influence the formation of the global status of countries, while implementing clustering the fact that the number of 
countries in these ratings varies was taken into account. Therefore, when determining the place of the states in the system of modern international relations, the data of only those of them were taken into consideration, the information about which was displayed in the reports of all developers at the same time. The 7th positions for each of 142 countries were subject to mathematical processing. The specificity of the information and the form of its presentation determined the use of hierarchical cluster analysis (HCA). This method, also known as hierarchical clustering, is popular in the case of the need to process a large array of data and their intellectual analysis aimed at creating a hierarchy of clusters (Murtagh and Contreras, 2011). It resulted in the construction of a dendrogram, obtained based on primary, subsequently aggregated and standardized indicators (Fig. 1).

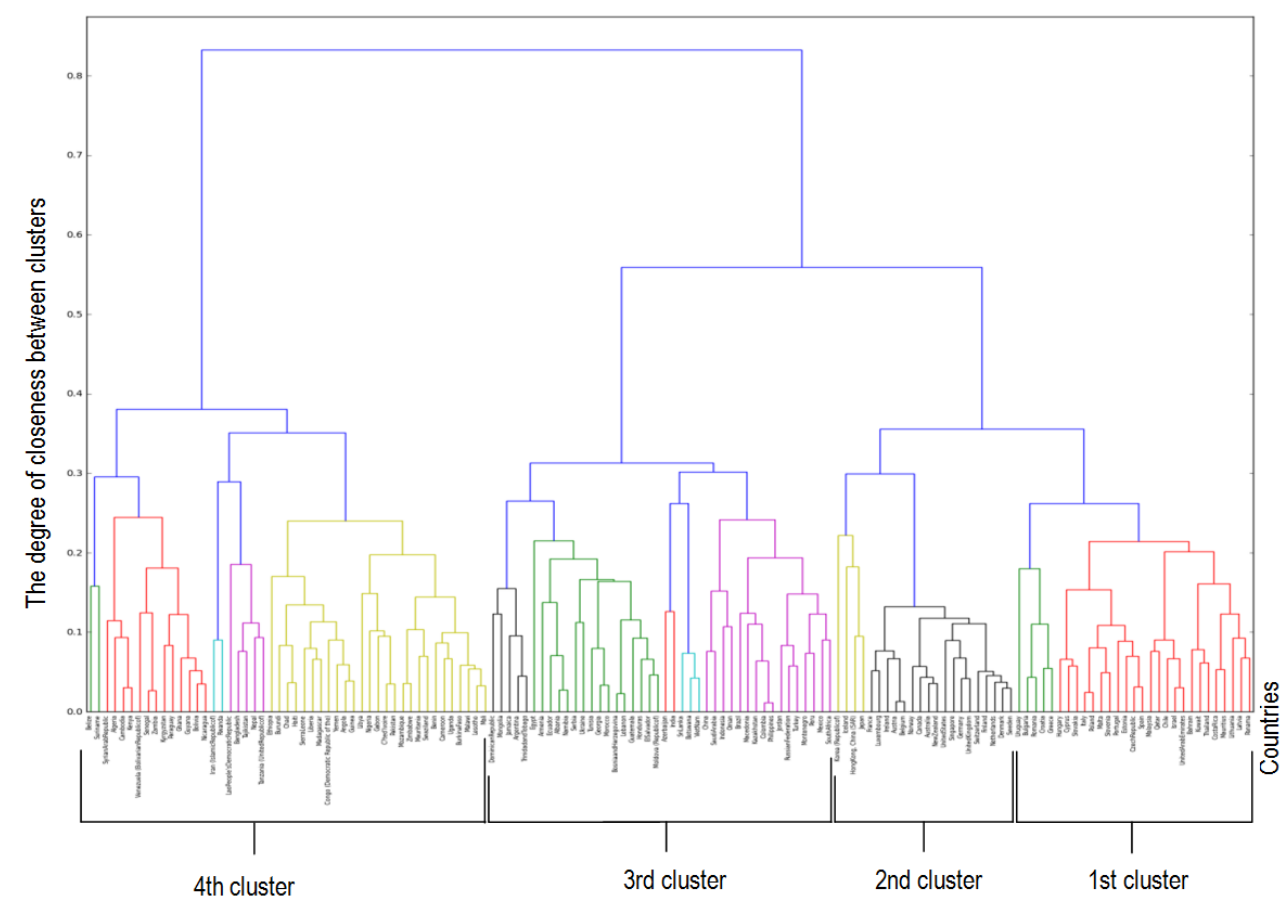

Figure 1. Clustering of countries based on their global status, 2018

Sources: developed by the authors based on rankings provided by KOF Swiss Economic Institute; The Legatum Institute; World Economic Forum; Cornell University, INSEAD, WIPO; United Nations; The Fund for Peace; Yale Center for Environmental Law and Policy.

The output of hierarchical cluster analysis is the number of groups/clusters that form the data set structure. As a result of the analysis 4 groups identified themselves most clearly, each of which is formed of smaller subgroups. The smallest by the number of countries (22 units), but the most compact in terms of similarity is the cluster number 2. It includes all world leaders - 6 countries from the G-7 (the USA, Japan, Germany, Great Britain, France, Canada), the most developed countries of Western Europe (Finland, Sweden, Norway, Denmark, Belgium, the Netherlands, Luxembourg, Switzerland, Austria) and some others.

Closest to cluster number 2 is cluster number 1 . It is made up of 29 countries, which follow the developed countries. These countries are directly close to the group of world leaders (in particular, Spain, Italy, Portugal, Israel); all countries of the CEE, called the first wave of accession to the EU (2004: Estonia, 
Latvia, Lithuania, Czech Republic, Slovakia, Poland, Hungary, Slovenia), the second wave (2007: Romania, Bulgaria) and the third wave (2013: Croatia); the countries the development of which is due to oil exports (Qatar, Kuwait, the United Arab Emirates), and others.

Cluster number 3 is close to a common block formed by the first and second clusters. It consists of 42 countries. The dendrogram represents the high branching of a hierarchical tree with a large number of nodes, which means the availability of a significant number of subgroups in the third cluster. The diversity of the cluster's representatives is confirmed by the fact that it includes newly industrialized countries (Brazil, Argentina, India, Indonesia), middle-income countries (the Philippines, Tunisia, Guatemala, Namibia), some CEE countries (Serbia, Ukraine, Bosnia and Herzegovina, Moldova, Macedonia), the Eastern Partnership countries (except Ukraine and Moldova, as well as Georgia, Azerbaijan, Armenia), some former USSR countries (Kazakhstan), former bloc of the socialist community countries (Vietnam) and others.

The most represented by the number of countries is the fourth cluster. It consists of 49 objects that are quite close to each other due to the similarity of the clustering sign - the place that countries occupy in the system of modern international relations. This group includes the majority of underdeveloped countries with a low global status. These are countries from Africa (Ethiopia, Burundi, Chad, Liberia, Angola, Guinea, Mozambique, Malawi) and Asia (Cambodia, Nepal, Pakistan). Cluster number 4 also includes some of the least developed countries from the former USSR (Kyrgyzstan, Tajikistan), and others. All countries included in this cluster are characterized by a small share of the processing industry in the economy, the weakness of state institutions, low living standards of the population, education and health of people, poor ecology, etc.

Conclusions. The results of the study allow us to determine the future development of the world society, leading to geo-economic, geopolitical and inter-civilizational asymmetries. A comparative analysis of the global status of countries allowed to identify the asymmetry as an imminent sign of a single (economic, political, social, spiritual) geospace of the modern world. The general conclusion is specified by the following provisions:

1. The highest global positioning characteristic of the countries united by the second cluster. These are the countries of the world's avant-garde. Mostly, the countries of the first cluster are close to them. Firstly, it is also represented by well-developed states with stable principles of the market economy, democracy, and a high standard of living for the population. Secondly, it includes the countries that have shown positive results in the aspiration for getting closer to the core zone in a planetary society. These are the countries with a high potential for progress, which can be achieved by different for each of the factors - the economy, political power, update and modification of the internal system order, availability of strategic resources, etc. At the same time, the countries of the third cluster with a variety of their socioeconomic and political forms of state organization are only catching up with the group of countries-leaders in the second turn. The countries of the fourth cluster are also participants in the processes taking place in the modern globalized world. Nevertheless, the global status gained by these countries, allows them to be only identified as outsiders. In other words, such countries are participants in a ramified system of economic, political, cultural and other ties between states (the dendrogram becomes complete with the inclusion of the fourth cluster countries). However, at the present stage of the development of a globalized society, they do not decisively influence the format of international relations.

2. Asymmetric development of countries creates a strong challenge to society. Its presence reflects the conflict between the national interests of the highly developed states and the rest of the world. Asymmetry is a harbinger of the confrontation between countries: first, technological, and then economic and political. It can also cause cultural, spiritual, and mental expansion of the stronger, in this sense, countries. Eventually, the confrontation may become a systemic contradiction, which means that the world is at the risk of a global catastrophe. 
3. However, the asymmetry phenomena that constantly arise in the modern economic life of society (as well as in the life of a globalized society as a whole) must be taken from the standpoint of dialectics. They objectify the preconditions for the creation of contradictions; serve as a kind of signal of their occurrence. Thus, asymmetries contain not only the potential of destruction but also the possibility of a qualitative restructuring of the modern world; they create the potential for the transition of a society to a higher level of its development. Economy, as the sphere in which the material basis of life and activity of the society is created, is progressing primarily because the mankind on a large segment of its history managed to move from the contradictions and asymmetries of the lower order to a higher one. It was their resolution, and not exacerbation, that allowed mega ostium to constantly move forward.

Strengthening the world hierarchy with economically unequal exchanges between countries and political relations not based on parity between them (the manifestation of asymmetry) is only one aspect of showing contradictions. At the same time there occur new points of world economic growth and alternative candidates for a change in the organization of the vital functions of a globalized society confidently declare themselves. The research into such changes is the subject of further scientific studies.

Author Contributions: Conceptualization, T. D.; methodology T. D. and O. S.; validity, Ks. V. and N. B.; formalization of analysis K. V.; study, O. S.; resources N. B.; software, K. V.; written and original project on preparation T. D., O. S., K. V.; written review and editing, O. S. and N. B.; visualization K. V.; project administration, $\mathrm{O}$. S.

\section{References}

A Modern Budget for a Union that Protects, Empowers and Defends: The new Multiannual Financial Framework 2021-2027 (2018). Commission Note ahead of the European Council. Retrieved from https://ec.europa.eu/commission/sites/betapolitical/files/euco-budget-booklet-june2018_en.pdf

Acemoglu D., Robinson J. (2017) Chomu natsii zanepadaiut pokhodzhennia vlady, bahatstva ta bidnosti [Why do nations fail the origin of power, prosperity, and poverty]. Kiev. Retrieved from https://theukrainians.org/why-nations-fail/ [in Ukrainian]

Beck U. (2012) Zhizn v obschestve globalnogo riska - kak s etimspravitsia: kosmopoliticheskii povorot [Living in the world risk society - how to deal with it: a cosmopolitan turn]. Bulletin of the Kennan Institute in Russia, 22. Retrieved from http://www.gorby.ru/userfiles/lekciya_ulrih_beka.pdf [in Russian]

Benoist A. (2012) Vpered, k prekrascheniiurosta! Ekologo-filosofskiitraktat [Forward to the cessation of growth! Ecological and philosophical treatise]. Moscow: Institute of Humanitarian Studies. Retrieved from https://www.libfox.ru>Книгиıforeign_edu [in Russian]

Environmental Performance Index 2018 (2018). Retrieved from https://epi.envirocenter.yale.edu/downloads/epi2018 policymakerssummaryv01.pdf

Fragile States Index Annual Report 2019 (2019). Retrieved from https://fragilestatesindex.org/wpcontent/uploads/2019/03/9511904-fragilestatesindex.pdf

Global Innovation Index 2018. Retrieved from https://www.wipo.int/edocs/pubdocs/en/wipo_pub_gii_2018.pdf

Greenacre M., Blasius J. (2006). Multiple Correspondence Analysis and Related Methods. Chapman \& Hall /CRC Press.

Heiets V. M., Hrytsenko A. A. (2016) Rekonstruktyvnyi ekonomichny i rozvytok: osnovninapriamy, efektyvnist i sotsialnaspravedlyvist [Reconstructive economic development: the main directions, efficiency and social justice]. Kiev: National Academy of Sciences of Ukraine, «Institute for Economics and Forecasting NAS of Ukraine». Retrieved from http://ief.org.ua/docs/scc/2.pdf [in Ukrainian]

Human Development Indices and Indicators 2018 Statistical Update (2018). Retrieved from http://hdr.undp.org/sites/default/ files/2018_human_development_statistical_update.pdf

Ikenberry J. (2016) Buduschee liberalnogo mirovogo poryadka [The future of liberal world order]. Multi-polar world; Analytics. Retrieved from http://russiancouncil.ru/inner/?id_4=8007\#top-content [in Russian]

Intriligator M. (2007) Hlobalizatsiia kak istochnik mezhdunarodnyi khkonfliktov i obostreniiakon kurentsii [Globalization as a source of international conflicts and aggravation of competition]. Problemyiteorii i praktikiupravleniia - Problems of theory and practice of management. Retrieved from http://vasilievaa.narod.ru/ptpu/6_6_98.htm [in Russian]

Kissinger H. (2015) Mirovoi poriadok [World order]. Moscow: AST Publishers [in Russian]

Kolodko Grzegorz W. (2013) Dokądzmierzaświat. Ekonomiapolitycznaprzyszlości [Where is the world going. Political Economy of the Future]. Warszawa: Prószyński S-ka [in Polish] 
Lukianenko D., Poruchnik A., Kolesov V. et al. (2013) Hlobalnoeekonomicheskoerazvitie: tendentsii, asimmetrii, regulirovanie [Global economic development: trends, asymmetries, regulation]. Kiev: KNEU named after Vadym Hetman [in Russian]

Madison E. (2012) Konturi mirovoi ekonomiki v 1-2030 gg. Ocherki po makroekonomicheskoi istorii [The contours of the global economy in 1-2030. Essays on macroeconomic history]. Moscow: Gaidar Institute Publishing [in Russian]

Mishenin E. V., Koblianska I. I. (2017) Perspektivy i mehanizmyrazvitiia «tsirkulyarnoi» ekonomiki v globalnoisrede [Prospects and mechanisms of development of the «circular» economy in the global environment]. Marketynh i menedzhment innovatsii Marketing and Management of Innovations, 2, 329-343 [in Russian]

Murtagh, Fionn and Contreras, Pedro (2011). Methods of Hierarchical Clustering. Computing Research Repository

Naisbitt J. (2003) Mehatrendi [Megatrends]. Moscow: AST CJSC NPP «Ermak» [in Russian]

Ostrom E. (2007) Institutional rational choice: Anassessmentoft he Institutional Analysis and Development Framework. Theories of the Policy Process. Cambridge, MA :WestviewPress. (pp. 21-64)

Polanyi K. (2002) Velikaiatransformatsiia: politicheskie i ekonomicheskieistokinashegovremeni [The great transformation: the political and economic origins of our time].St. Petersburg: Aletheia. Retrieved from https://coollib.com/b/184360 [in Russian]

Poliovyk S. (2018) ProektbiudzhetuYeSna 2021-2027 rr. tayohoznachenniadliaUkrainy [The Draft EU budget for 2021-2027 and its significance for Ukraine]. Analytical Center «Borisfen Intel». Retrieved from http://bintel.com.ua/uk/article/05_19_eu/

Ranking. KOF Globalisation Index: Globalisation Lull Continues (2018). Retrieved from https://kof.ethz.ch/en/news-andevents/media/press-releases/2018/12/kof-globalisation-index-globalisation-lull-continues.html

Sachs D. Jeffrey (2011) The Price of Civilization. New York and London: Random House

Tarasevich V. M. (2017) Fundamentalnia ekonomicheskai anauka: universumnostsoderzhaniia i razvitiia [Fundamental economics: the universality of content and development]. Dnipro: PJSC «Economics» [in Russian]

The Global Competitiveness Report 2018 (2018). Retrieved from http://www3.weforum.org/docs/GCR2018/05FullReport/ TheGlobalCompetitivenessReport2018.pdf

The Legatum Prosperity Index 2018 (2018). Retrieved from Retrieved from https://prosperitysite.s3accelerate.amazonaws.com/2515/4321/8072/2018_Prosperity_Index.pdf

Wallerstein I. (2004) Konetsznakomogomira: Sotsiologiya XXI veka. [The end of the familiar World: Sociology of the 21st century.] Moscow: Logos. Retrieved from http://yanko.lib.ru/books/cultur/vallerstayn-konec_znakomogo_mira-8l.pdf. [in Russian]

Yurchyshyn V. (2018) Hlobalnitendentsii i perspektyvy: svitovaekonomika ta Ukraina [Global Trends and Prospects: The World Economy and Ukraine]. Kiev: Zapovit [in Ukrainian]

Zaitsev Yu. K. (2016) Transformatsiiatsinnisnykhoriientyrivrozvytkusuchasnoiekonomiky: formyproiavu, problemy ta perspektyvy [Transformation of value orientations for the development of the modern economy: forms of manifestation, problems and perspectives]. Ekonomichnateoriia ta pravo - Economic theory and law, 3 (26), 11-26. [in Ukrainian]

Тетяна Дейнека, д.е.н., доцент, Вищий навчальний заклад Укоопспілки «Полтавський університет економіки і торгівлі» (Україна);

Ольга Шкурупій, д.е.н., профресор, Вищий навчальний заклад Укоопспілки «Полтавський університет економіки і торгівлі» (Україна);

Ксенія Вергал, к.е.н., доцент, Вищий навчальний заклад Укоопспілки «Полтавський університет економіки і торгівлі» (Україна);

Наталія Базавлук, к.е.н., дочент, Вищий навчальний заклад Укоопспілки «Полтавський університет економіки і торгівлі» (Україна).

Глобальний статус країн: визначення та інтерпретація

Дослідження місия і ролі країн у системі сучасних міжнародних відносин зумовлена необхідністю виявлення асиметрій і суперечностей, які властиві суспільству, що глобалізується. Метою статті $\epsilon$ визначення глобального статусу країн та тлумачення наявного стану їх позиціонування. Узагальнення наукових засад, що формують уявлення про стан, в якому перебуває нині глобальне суспільство та варіанти його можливої транссрормації, підтверджує актуальність аналізу за цією проблематикою. В статті представлено підхід до параметричної оцінки глобального статусу країн, необхідність якого обумовлена невирішеністю чієї проблеми у тематичному полі зазначених наукових досліджень. Методологічною основою визначення глобального статусу країн $\epsilon$ узагальнення результатів дії внутрішніх чинників розвитку національних систем за сфрерами (економічною, технологічною, соціальною та духовно-культурною, політичною та функціонування державних інститутів, природокористування), синергетичного ефекту взаємозалежності всіх складових таких соціоприродних комплексів (дії агрегованого ендогенного чинника) та результату впливу глобалізації (дії екзогенного чинника). За сукупністю оцінки ситуації, статуси країн відображають наявну картину світу та розстановку сил в системі сучасних міжнародних відносин, а також розглядається як фрункціонал перетворення глобалізованого світу. Методом наукового 
аналізу є агломераційна кластеризація, проведена за допомогою програмного алгоритму та реалізована мовою Python. Емпіричний аналіз базується на даних міжнародних організацій за 2018 р. До аналізу залучені данні за 142 країнами. Дослідження емпірично підтверджують та теоретично доводять факт асиметричності сучасного світу, що є істотним викликом глобалізованому суспільству. У той же час виникнення асиметрії є попередженням; сигналом про наявність загрози системної суперечності глобального маситабу. Отже, асиметрії містять не тільки потенціал руйнації, але й потенціал якісно кращої перебудови світу. Врахування цього фракту та постійний моніторинг змін на основі оцінки глобального статусу країн дозволяє визначити варіанти, за якими відбуватиметься розвиток цивілізації у майбутньому і попередити такі негативні явища як глобальні проблеми, ризики, кризи та інші, включаючи також глобальну катастрофу.

Ключові слова: глобалізація, глобалізоване суспільство, глобальний статус країн, позиціонування країн, суперечність, асиметричність.

Manuscript received: 21.08.2019.

(C) The author(s) 2019. This article is published with open access at Sumy State University. 